Gelanggang Olahraga: Jurnal Pendidikan Jasmani dan Olahraga

Volume 1, Nomor 2, Januari-Juni 2018

e-ISSN : 2597-6567

p-ISSN : 2614-607X

DOI : https://doi.org/10.31539/jpjo.v1i2.136

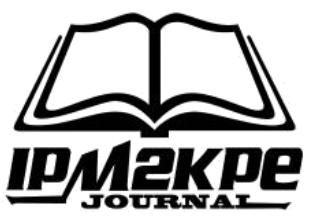

\title{
STUDI TENTANG TINGKAT KESEGARAN JASMANI MAHASISWA PENJASKES STKIP-PGRI LUBUKLINGGAU
}

\author{
Azizil Fikri \\ STKIP-PGRI Lubuklinggau \\ azil_azizil@yahoo.com
}

\begin{abstract}
ABSTRAK
Penelitian ini bertujuan untuk mengetahui bagaimana tingkat kesegaran jasmani mahasiswa Penjaskes STKIP-PGRI Lubuklinggau. Jenis penelitian ini adalah deskriptif yaitu mendiskripsikan, mengungkapkan, dan menapsirkan data yang berhubungan dengan tingkat kesegaran jasmani mahasiswa Penjaskes. Populasi penelitian ini adalah mahasiswa Penjaskes angkatan 2016 sebanyak 18 orang yang dilaksanakan dilingkungan kampus STKIP-PGRI Lubuklinggau. Teknik pengambilan data penelitian ini adalah dengan tes dan pengukuran. Untuk mengukur tingkat kesegaran jasmani mahasiswa Penjaskes STKIP-PGRI Lubuklinggau dipergunakan tes cooper lari $2,4 \mathrm{~km}$. Teknik analisis data yang digunakan adalah teknik analisis persentase. Hasil penelitian menyatakan bahwa 8 orang $(44,44 \%)$ memiliki kesegaran jasmani baik sekali. 6 orang $(33,33 \%)$ memiliki kesegaran jasmani baik, 4 orang $(22,22 \%)$ memiliki tingkat kesegaran jasmani kurang, sedangkan memiliki tingkat kesegaran jasmani kurang dan kurang sekali tidak ada $(0,00 \%)$.
\end{abstract}

Kata Kunci : Kesegaran Jasmani, Mahasiswa Penjaskes

\section{ABSTRACT}

This study aims to determine how the level of physical fitness students Penjaskes STKIP-PGRI Lubuklinggau. The type of this research is descriptive that is to describe, express, and to get data related to physical fitness level of student of Penjaskes. Population of this research is student of Penjaskes force of 2016 as many as 18 people which conducted in environment campus STKIP-PGRI Lubuklinggau. Technique of collecting data of this research is by test and measurement. To measure the level of physical fitness of students Penjaskes STKIP-PGRI Lubuklinggau used $2.4 \mathrm{~km}$ cooper test run. Data analysis technique used is percentage analysis technique. The results stated that 8 people (44.44\%) had very good physical fitness. 6 people (33.33\%) have good physical fitness, 4 people $(22.22 \%)$ have less physical fitness level, whereas they have less physical fitness and less than none $(0,00 \%)$.

Keywords: Physical Freshness, Student Penjaskes 


\section{PENDAHULUAN}

Bangsa Indonesia merupakan bangsa yang sedang berkembang, yang mana pembangunan di segala bidang merupakan tujuan utamanya. Setiap pembangunan diharapkan berdasarkan ilmu pengetahuan dan teknologi. Untuk mendapatkan hasil IPTEK yang memuaskan, kita juga perlu membangun bidang olahraga, baik olahraga untuk mencapai prestasi maupun olahraga untuk kesegaran jasmani. Dalam berolahraga diharapkan terciptanya masyarakat yang sehat jasmani dan rohani. Di samping itu, kegiatan olahraga diharapkan membentuk watak dan kepribadian-kepribadian yang baik. Dengan hal tersebut dapat tercipta manusia yang seutuhnya dalam mengisi pembangunan. Oleh karena itu olahraga perlu ditingkatkan dan disebarluaskan di pelosok tanah air agar masyarakat lebih menggemari olahraga.

Sehubungan dengan hal di atas pemerintah mengeluarkan Undang-Undang Sistem Keolahragaan Nasional No. 3 tahun 2005 yaitu:

Pembinaan dan pengembangan keolahragaan nasional yang dapat menjamin pemerataan akses terhadap olahraga, peningkatan kesehatan dan kebugaran, peningkatan prestasi, dan menajemen keolahragaan yang menghadapi tantangan-tantangan serta tuntutan perubahan kehidupan nasional dan global memerlukan system pembinaan olahraga untuk mencapai prestasi

Berdasarkan kutipan di atas menunjukkan bahwa dalam pembangunan nasional sangat berintegrasi dengan pembangunan kebudayaan bangsa, yang dapat membawa kearah kesatuan dan persatuan dalam mencapai tujuan pembangunan yakni masyarakat aman, adil dan makmur serta sehat jasmani dan rohani. Dalam pembangunan nasional sangat berintegrasi dengan pembangunan kebudayaan bangsa, yang dapat membawa ke arah kesatuan dan persatuan dalam mencapai tujuan pembangunan yakni masyarakat aman, adil dan makmur serta sehat jasmani dan rohani. Untuk mencapai tujuan di atas, maka perlu ditingkatkan usaha-usaha seperti mengadakan latihan secara berkelanjutan, bahkan perlombaan olahraga yang dapat diikuti oleh seluruh lapisan masyarakat. Hal ini diharapkan dapat menjaga dan meningkatkan kesegaran jasmani karena pelaksanaannya lebih terarah dan teratur.

Pembinaan kesehatan melalui salah satu aspek, khususnya melalui kegiatan jasmani atau olahraga juga berpengaruh terhadap aspek lainnya. Sebagaimana dijelaskan oleh Frost dalam Abdullah dan Agusmunaji (1994) mengemukakan bahwa kesegaran dalam kontek luas hampir sinonim dengan sehat, kesegaran jasmani adalah kesejahetraan tingkat tinggi dan mencakup tanpa ada sesuatu yang merugikan atau merintangi dan penyakit yang dapat disembuhkan, serta berfungsinya secara optimal semua sistem tubuh dan semangat-semangat tinggi untuk bekerja maupun bermain. Dari kutipan di atas jelas bahwa kesegaran jasmani sangat dibutuhkan dalam aktivitas sehari-hari. Baik itu yang bersifat aktivitas maupun yang bersifat berfikir. Dalam hal ini, kesegaran jasmani sangat dibutuhkan oleh mahasiswa Penjaskes, karena berkaitan dengan aktifitas mereka dalam pembelajaran yakni teori dan praktek di lapangan. Kemudian agar tubuh terhindar dari penyakit, maka kita harus meningkatkan 
kesegaran jasmani yang bersifat fisik, sehingga sangat dibutuhkan kesegaran jasmani yang tinggi dalam beraktifitas.

Jurusan Penjaskes mempelajari tentang cabang olahraga dan anatomi tubuh manusia, lebih mengutamakan kegiatan bersifat fisik. Kegiatan perkuliahan terdiri dari teori dan praktek, dalam ruangan dan lapangan yang membutuhkan tenaga dan fisik yang bugar dan kuat. Tenaga mahasiswa jurusan Penjaskes lebih banyak terkuras dibandingkan mahasiswa lainnya. Maka dari itu, sangat penting dalm menjaga kesegaran jasmani.

Berdasarkan gambaran di atas, peneliti mencoba menganalisa tingkat kesegaran jasmani mahasiswa Penjaskes tersebut. Kemudian setelah melakukan pembelajaran olahraga, mereka seolah-olah mengeluarkan tenaga yang cukup besar dibandingkan mahasiswa jurusan lainnya. Maka dari itu, sangat dibutuhkan tingkat kesegaran jasmani yang baik bagi mahasiswa Penjaskes STKIP-PGRI Lubuklinggau, diantaranya; kesegaran jantung, kelentukan, ketahanan otot dan kekuatan otot. Namun dari hasil pengamatan dalam kegiatan sehari-hari di lingkungan mahasiswa Penjaskes STKIP-PGRI Lubuklinggau ditemukan beberapa kejanggalan yang ada kaitannya dengan kesegaran jasmani seperti, terjadinya kelelahan, cepat ngantuk, kurang gairah dan cepat merasa capek. Hal ini disebabkan oleh banyaknya faktor seperti lingkungan, usia, gizi, aktifitas.

Dari kenyataan tersebut dimana perlu dilakukan suatu penelitian yang mengungkapkan secara ilmiah tentang keadaan tingkat kesegaran jasmani mahasiswa Penjaskes STKIP-PGRI Lubuklinggau. Salah satu kesegaran jasmani yang akan dilihat adalah ketika dilaksanakan tes cooper $2,4 \mathrm{~km}$. Berdasarkan masalah di atas, maka tujuan dari penelitian ini adalah untuk mengetahui tingkat kesegaran jasmani mahasiswa Penjaskes STKIP-PGRI Lubuklinggau.

Berdasarkan uraian di atas, penulis tertarik untuk mengungkapkan tingkat kesegaran jasmani mahasiswa Penjaskes Angkatan 2016 STKIP-PGRI Lubuklinggau yang dilakukan dengan metode tes cooper 2,4 km, kemudian mendeskripsikan jurnal ini dengan judul "Studi tentang Tingkat Kesegaran Jasmani Mahasiswa Penjaskes Angkatan 2016 STKIP-PGRI Lubuklinggau”. Tujuan dari penelitian ini adalah untuk mengetahui tingkat kesegaran jasmani mahasiswa Penjaskes angkatan 2016 STKIP-PGRI Lubuklinggau.

\section{KAJIAN TEORI \\ Kesegaran Jasmani}

Menurut Frost dalam Abdullah dan Agusmunaji (1994) mengemukakan bahwa kesegaran dalam konteks luas hampir sinonim dengan sehat, kesegaran jasmani adalah kesejahteraan tingkat tinggi dan mencakup tanpa ada sesuatu yang merugikan atau merintangi dan penyakit yang dapat disembuhkan, serta berfungsinya secara optimal semua sistem tubuh dan semangat tinggi untuk bekerja maupun bermain. Menurut Sutarman dalam Arsil (1999) kesegaran jasmani adalah suatu aspek fisik dari kesegaran yang menyeluruh (total fitness), yang memberikan kesanggupan kepada seseorang yang menjalani hidup yang produktif dan dapat menyesuaikan diri pada tiap-tiap perubahan fisik yang layak. Menurut Sudoso (1990) kesegaran jasmani adalah kemampuan seseorang untuk menunaikan tugasnya sehari-hari dengan mudah, tanpa merasa lelah 
berlebihan serta mempunyai sisa atau cadangan tenaga untuk menikmati waktu senggangnya dan untuk keperluan mendadak. Kemudian dikemukakan Getchell dalam Sunardi (1998) bahwa "Kesegaran jasmani adalah suatu hal yang menitikberatkan pada fungsi fisiologis yaitu kemampuan jantung, pembuluh darah, paru-paru dan otot yang berfungsi secara efisien dan efektif". Secara lebih khusus jasmani serta fungsi organ tubuh manusia nampak dalam keadaan fungsi jantung, paru-paru, ginjal, hati, keadaan syaraf sentral, persendian, otot, kulit, cairan tubuh.

Berdasarkan pendapat di atas, kesegaran jasmani meliputi keadaan sehat jasmani dan kemampuan kerja secara efisien tanpa menimbulkan kelelahan yang berarti. Dengan demikian, kesegaran jasmani merupakan modal utama dalam melaksanakan pekerjaan sehari-hari sesuai kebutuhan. Artinya kesegaran jasmani merupakan cermin dari kemampuan fungsi sistem dalam tubuh yang dapat mewujudkan peningkatan kualitas hidup dalam setiap aktifitas fisik.

Tingkat kesegaran jasmani yang baik akan mencerminkan ciri-ciri sebagai berikut; 1) Cukup kuat melakukan tugas harian maupun tugas darurat atau mendadak lainnya, 2) Mempunyai kemampuan untuk menyelesaikan tugas harian tanpa kelelahan yang berarti, 3) Mempunyai ketahanan kardiovaskuler untuk melakukan pekerjaan yang melelahkan, 4) Memiliki kelincahan sehingga mampu untuk bergerak leluasa, 5) Memiliki kecepatan untuk mampu bergerak cepat dalam mengatasi keadaan darurat, 6) Memiliki daya kontrol mengkoordinasikan gerakan tubuh dengan mulus (Sunardi, 1998).

Berdasarkan pandangan di atas jelas bahwa tingkat kesegaran jasmani yang rendah akan memiliki dampak dalam kegiatan yang dilakukan seharihari. Hal ini sangat mempengaruhi bila seorang pelajar mengalami tingkat kesegaran jasmani rendah atau kurang, maka ia akan terkendala dalam proses belajar mengajar sehingga akan berakibat pada pencapaian prestasi belajar. Sebaliknya, orang yang memiliki kesegaran jasmani yang baik akan mampu melakukan aktifitas atau beban fisik yang dihadapi dalam kehidupan seharihari dan masih menyisakan tenaga untuk mengisi waktu luang.

\section{Komponen-KomponenKesegaran Jasmani}

Kesegaran jasmani terdiri dari beberapa komponen menurut Sudarno (1992) yaitu daya tahan kardiovaskuler (Cardiovascular Endurance), daya tahan otot (Muscle Endurance), kekuatan otot (Muscle Strength), kelentukan (Flexibility), komposisi tubuh (Body Composition), kecepatan gerak (Speed of Movement), kelincahan (Agility), keseimbangan (Balance), kecepatan reaksi (Reaction Time) dan koordinasi (Coordination). Dari 10 komponen tersebut para ahli kesehatan berpendapat bahwa komponen daya tahan adalah komponen terpenting dalam menentukan kesegaran jasmani seseorang. Menurut Darwin (1992) daya tahan adalah kemampuan organism atlet untuk mengatasi kelelahan yang timbul setelah melakukan aktifitas tubuh berolahraga dalam waktu lama, daya tahan dapat ditafsirkan sebagai kualitas fisik (sistem jantung, peredaran darah dan pernapasan) yang membuat seseorang mampu melaksanakan secara terus-menerus suatu kerja fisik yang cukup berat tanpa merasa lelah sebelum waktunya. 
Menurut Djoko (2004), komponen kesegaran jasmani diklasifikasikan dalam dua kategori yaitu berkaitan dengan kesehatan dan keterampilan gerak. Komponen yang berkaitan dengan kesehatan menyangkut perkembangan kualitas yang dibutuhkan untuk efisiensi fungsional dan pemeliharaan gaya hidup sehat. Komponen meliputi :

1. Daya tahan jantung paru (kemampuan jantung paru menyuplai oksigen untuk kerja otot dalam waktu yang lama).

2. Kekuatan dan daya tahan otot (kemampuan kelompok otot melawan beban dalam satu usaha dan melakukan serangkaian kerja dalam waktu cukup lama).

3. Kelentukan (kemampuan persendian untuk bergerak secara leluasa).

4. Komposisi tubuh (perbandingan berat badan atau tubuh tanpa lemak dinyatakan prosentase lemak tubuh).

Menurut Djoko (2004), "Keberhasilan untuk mencapai kesegaran ditentukan oleh kualitas latihan yang meliputi: tujuan latihan, pemilihan model latihan, sarana latihan dan dosis latihan konsep FIT (Frecuency, Intensity, and Time)". Frecuency adalah unit latihan persatuan waktu, latihan 3-5 kali perminggu. Intensity adalah berat atau ringannya kualitas latihan, 75\% - 85\% detak jantung maksimal, dihitung dengan cara 220-umur (dalam tahun). Time adalah durasi yang diperlukan setiap kali latihan, waktu berlatih 20-60 menit.

Kesegaran jasmani akan dapat diraih dan ditingkatkan melalui proses latihan teratur, berkesinambungan dan sistematis. Sebagaimana diungkapkan Harsono (1988), latihan adalah proses sistematis dari berlatih atau bekerja, yang dilakukan secara berulang dengan kian hari kian menambah jumlah beban latihan atau pekerjaannya.

\section{Faktor yang Mempengaruhi Kesegaran Jasmani}

Banyak faktor yang mempengaruhi kesegaran jasmani seperti: a) aktifitas fisik dan kegiatan olahraga yang dilakukan sehari-hari, b) makanan bergizi. Pengaturan gizi makanan harus mendapat perhatian dalam upaya pembinaan kesegaran jasmani, sehingga sesuai dengan tingkat kebutuhan kalori yang diperlukan. Sebaiknya makanan bergizi tersebut mempunyai nilai karbohidrat, protein, lemak, vitamin dan mineral agar aktifitas yang dilakukan tidak terhalang dengan kurangnya tingkat kesegaran jasmani. Semakin banyak dan lengkap sari makanan yang terdapat di dalam bahan makanan, akan semakin tinggi nilai gizinya dan c) perkembangan teknologi yang pesat, sehingga pergerakan manusia lebih cenderung ringan, mudah dan tidak memerlukan aktifitas fisik yang banyak, sehingga berdampak pada kesegaran jasmani itu sendiri.

\section{Tes Cooper Lari 2,4 Km}

Teknik pengumpulan data dalam penelitian ini adalah tes Cooper, yaitu lari 2400 meter (Cooper dalam Arsil 1999). Tes ini diciptakan oleh Cooper seorang ahli tes pendidikan Jasmani dan Olahraga. Tujuannya untuk mengukur kondisi fisik kesegaran Jasmani seseorang melalui pengukuran aerobik berlari sejauh 2400 
meter. Alat yang digunakan adalah : stopwatch, alat tulis berupa kertas dan pena. Tempat tes : Lintasan Lari dengna keliling 400 meter.

Peserta tes harus berlari secepat-cepatnya menempuh jarak 2,4 km. Lintasan tes $2,4 \mathrm{~km}$ berstruktur datar, tidak bergelombang, tidak licin, tidak terlalu banyak belokan tajam. Garis start untuk mengawali tes dirancang sedemikian rupa hingga jarak finish sama, artinya garis start sama dengan garis finish. Hal ini dilakukan untuk memudahkan pengetes. Waktu tempuh yang dicapai oleh peserta tes dicatat dalam satuan menit dua angka di belakang koma. Waktu tersebut digunakan untuk memprediksi tingkat kesegaran mahasiswa dengan cara mengkonfirmasikan dengan tabel tingkat kesegaran jasmani milik Cooper. Tes ini dilakukan untuk kelompok umur:

1. Kelompok laki-laki dan perempuan berumur di bawah 30 tahun

2. Kelompok laki-laki dan perempuan berumur 30 tahun sampai 39 tahun

3. Kelompok laki-laki dan perempuan berumur 40 tahun sampai 49 tahun

4. Kelompok laki-laki dan perempuan berumur di atas 50 tahun

Peserta yang melakukan tes harus dinyatakan sehat dan menggunakan pakaian olahraga yang nyaman dan sopan. Kemudian dilakukan pencatatan denyut nadi. Para peserta tes diberi kesempatan untuk melakukan pemanasan 10-15 menit. Setelah itu peserta tes berlari $2,4 \mathrm{~km}$ ditandai dengan aba-aba pada saat itu stopwatch dihidupkan. Setelah mencapai garis finish dengan kaki menginjak garis finish, stopwatch dimatikan yang kemudian diukur catatan waktunya dan setelah itu diukur kembali denyut nadinya. Setelah berselang 15 menit diukur kembali denyut nadinya.

Untuk mengetahui klasifikasi kesegaran jasmani, waktu tes yang di tempuh dicocokkan dengan tabel norma yang berlaku menurut kelompok umur dan jenis kelamin

Tabel 1

Penilaian Tes Lari 2400 Meter

\begin{tabular}{cc}
\hline Waktu & Kategori \\
\hline Lebih dari 18 & Sangat Baik \\
\hline $14.30-17.59$ & Baik \\
\hline $12.05-14.29$ & Sedang \\
\hline $10.20-12.04$ & Kurang \\
\hline Kurang dari 10.19 & Sangat Kurang \\
\hline
\end{tabular}

\section{METODE PENELITIAN}

Jenis penelitian ini adalah deskriptif, penelitian ini tertuju pada pengungkapan suatu keadaan sebagaimana adanya sesuai dengan pendapat yang dikemukakan oleh Arikunto (1997) yang mengatakan bahwa "penelitian deskriptif merupakan penelitian yang dimaksudkan untuk mengumpulkan informasi mengenai status gejala menurut apa adanya pada saat penelitian dilakukan". Penelitian ini akan mendeskripsikan, mengungkapkan dan menapsirkan data yang 
berhubungan dengan tingkat kesegaran jasmani Mahasiswa Penjaskes Angkatan 2016 STKIP-PGRI Lubuklinggau.

\section{Populasi dan Sampel}

Berdasarkan judul penelitian ini yaitu "Studi tentang Tingkat Kesegaran Jasmani Mahasiswa Penjaskes Angkatan 2016 STKIP-PGRI Lubuklinggau", maka yang menjadi populasi dalam penelitian ini adalah Mahasiswa Putra STKIP-PGRI Lubuklinggau yang berjumlah 18 orang dan karena jumlah populasi tidak terlalu besar, maka teknik sampel yang digunakan dalam penelitian ini adalah total sampling, artinya seluruh populasi dijadikan sampel penelitian yang berjumlah 18 orang.

\section{Jenis dan Sumber Data}

Berdasarkan tujuan yang hendak dicapai dalam usaha untuk mengungkapkan permasalahan yang berkaitan dengan "Studi tentang Tingkat Kesegaran Jasmani Mahasiswa Penjaskes Angkatan 2016 STKIP-PGRI Lubuklinggau", maka diperlukan data primer. Data primer adalah data yang diperoleh langsung dari responden di lapangan yakni dari seluruh mahasiswa Penjaskes angkatan 2016 STKIP-PGRI Lubuklinggau. Diharapkan dengan data tersebut dapat mengungkapkan keadaaan tentang kesegaran jasmani mahasiswa Penjaskes angkatan 2016 STKIP-PGRI Lubuklinggau.

Data yang diperoleh dalam penelitian ini diambil langsung dari prodi Penjaskes STKIP-PGRI Lubuklinggau yang mana diujikan langsung kepada responden (Mahasiswa Penjaskes angkatan 2016 STKIP-PGRI Lubuklinggau).

\section{Teknik Pengumpulan Data}

Tes ini diciptakan oleh Cooper seorang ahli tes Pendidikan Jasmani dan Olahraga. Tujuannya untuk mengukur kondisi fisik kesegaran jasmani seseorang melalui pengukuran aerobik berlari sejauh 2400 meter. Alat yang digunakan adalah: stopwatch, alat tulis berupa kertas dan pena. Tempat tes: Lintasan Lari dengan keliling 400 meter.

\section{Instrumen Penelitian}

Untuk mengetahui klasifikasi kesegaran jasmani, waktu tes yang di tempuh dicocokkan dengan tabel norma yang berlaku menurut kelompok umur dan jenis kelamin.

Tabel 2.

Kategori Kesegaran Jasmani

\begin{tabular}{cc}
\hline Waktu & Kategori \\
\hline Lebih dari 18 & Sangat Baik \\
\hline $14.30-17.59$ & Baik \\
\hline $12.05-14.29$ & Sedang \\
\hline $10.20-12.04$ & Kurang \\
\hline Kurang dari 10.19 & Sangat Kurang \\
\hline
\end{tabular}




\section{Teknik Analisis Data}

Data yang ditampilkan dalam penelitian ini dianalisis melalui tabulasi frekuensi statistik deskriptif dengan formula sebagai berikut:

$$
P=\frac{F}{N} X 100 \%
$$

Keterangan :

$$
\begin{aligned}
& \mathrm{P}=\text { Persentase } \\
& \mathrm{F}=\text { Frekuensi (skor yang diperoleh) } \\
& \mathrm{N}=\text { Jumlah sampel (Sudjiono, 1991) }
\end{aligned}
$$

\section{HASIL PENELITIAN \\ Deskripsi Data Penelitian}

Deskripsi data hasil tes kesegaran jasmani lari 2400 meter terhadap mahasiswa Penjaskes angkatan2016, secara distribusi frekuensi dapat digambarkan sebagai berikut :

Tabel 3

Deskripsi Data Penelitian

\begin{tabular}{cccccc}
\hline Res & N & Mean & Std. Dev & Min & Mak \\
\hline Putra & 18 & 10.47 & 1.33 & 9.33 & 14.20 \\
\hline
\end{tabular}

Dari tabel di atas dijelaskan hasil analisis tingkat kesegaran jasmani mahasiswa Penjaskes angkatan 2016 STKIP-PGRI Lubuklinggau dengan jumlah responden 18 orang, diperoleh rerata hitung $($ mean $)=10.47$, standar deviasi $=$ 1.33, nilai minimum $=9.33$ dan maksimum $=14.20$.

Selanjutnya dalam deskripsi ini disajikan distribusi tingkat kesegaran jasmani mahasiswa Penjaskes angkatan 2016 STKIP-PGRI Lubuklinggau dari responden

\begin{tabular}{|c|c|c|c|c|}
\hline No & Klafikasi & Hasil Tes (menit) & $\mathbf{F a}$ & Fr \\
\hline 1 & Baik Sekali & Kurang dari 10.19 & 8 & 44.44 \\
\hline 2 & Baik & $10.20-12.04$ & 6 & 33.33 \\
\hline 3 & Sedang & $12.05-14.29$ & 4 & 22.22 \\
\hline 4 & Kurang & $14.30-17.59$ & 0 & 0.00 \\
\hline 5 & Sangat Kurang & Lebih dari 18 & 0 & 0.00 \\
\hline \multicolumn{3}{|c|}{ Jumlah } & 18 & 100.0 \\
\hline
\end{tabular}
penelitian yang sesuai klasifikasi tes kesegaran jasmani lari 2400 meter sebagai berikut

Tabel 4

Distribusi Frekuensi Tingkat Kesegaran Jasmani

Sesuai data yang dikumpulkan dari 18 responden penelitian mewakili mahasiswa putra diperoleh penyebaran jawaban berdasarkan tingkat klasifikasi sebagai berikut, klasifikasi "Baik Sekali" frekuensi $=8$ (44.44\%) "Baik" frekuensi $=6$ (33.33\%), 
"Sedang "frekuensi $=4$ (22.22\%), "Kurang" frekuensi $=0(0.00 \%)$, dan "Kurang Sekali" $=0(0.00 \%)$.

\section{PEMBAHASAN}

Berdasarkan temuan penelitian yang telah diuraikan di atas, kesegaran jasmani merupakan aspek fisik dari kesegaran yang menyeluruh (total fitness) yang memberikan kesanggupan pada seseorang untuk menjalankan hidup yang produktif dan dapat menyesuaikan diri terhadap pembebanan fisik (physical stress) yang layak. Begitu juga halnya dengan mahasiswa terutama pada jurusan Penjaskes, mereka sebaiknya memiliki tingkat kesegaran jasmani yang baik agar bisa melaksanakan tugas dan kegiatan sehari-hari dengan baik dan efisien tanpa merasakan kelelahan dalam tubuh dan masih memiliki tenaga cadangan baik untuk mengatasi keadaan darurat maupun untuk menikmati waktu senggang dengan rekreasi yang aktif.

Pada dasarnya kesegaran jasmani seseorang dipengaruhi oleh aktivitas fisik dan olahraga yang dilakukan sehari-hari. Semakin baik aktivitas fisik yang dilakukan seseorang maka semakin baik pula tingkat kesegaran jasmaninya. Dari hasil analisis deskriptif data penelitian diketahui bahwa dari 18 responden menunjukkan bahwa tingkat kesegaran jasmani mahasiswa menurut klasifikasi kesegaran jasmani lari 2400 meter yaitu berada pada klasifikasi "baik sekali" sebanyak 8 orang atau $44.44 \%$, klasifikasi "baik" sebanyak 6 orang atau 33.33\%, klasifikasi "sedang" sebanyak 4 orang atau 22.22\%, klasifikasi "kurang" dan klasifikasi kurang sekali tidak ada.

Berpedoman pada hasil tinjauan tingkat kesegaran jasmani mahasiswa Penjaskes angkatan 2016 STKIP-PGRI Lubuklinggau dapat dikatakan bahwa secara keseluruhan tingkat kesegaran jasmani mahasiswa berada pada kategori baik. Hal ini dibuktikan dari persentase tingkat kesegaran jasmani umumnya pada kategori baik sekali. Ada banyak faktor yang menyebabkan hal ini terjadi, sebagaimana yang dikemukan Hafen dalam Sunardi Soesasmito (1998) bahwa ada dua kriteria untuk mencapai tingkat kesegaran jasmani. Pertama, komponen kesehatan. Komponen ini terdiri dari empat hal pokok yaitu daya tahan cardio vascular, daya tahan dan kekuatan otot, keseimbangan pertumbuhan tubuh serta kelentukan. Kedua, komponen keterampilan yang terdiri dari daya tahan, kekuatan otot, tenaga ledak otot, kecepatan dan ketangkasan.

Hal ini dikuatkan oleh pendapat Bowers dalam Arsil (1999) yang menyatakan bahwa "daya tahan merupakan salah satu komponen biomotorik yang sangat dibutuhkan dalam aktivitas fisik, dan salah satu komponen terpenting dari kesegaran jasmani". Kutipan ini menjelaskan bahwa seseorang yang memiliki daya tahan tubuh yang tinggi, maka kondisi tubuhnya akan mampu bekerja dalam waktu yang lama tanpa mengalami kelelahan yang berarti atau berlebihan. Semua komponen ini sangat diperlukan pada semua aktivitas fisik seseorang, termasuk mahasiswa.

Merujuk pada hasil penelitian yang menyatakan bahwa tingkat kesegaran jasmani mahasiswa umumnya pada klasifikasi sangat baik, maka dapat disimpulkan bahwa komponen-komponen kesegaran jasmani sangat berperan dalam aktivitas fisik mahasiswa Penjaskes angkatan 2016 STKIP-PGRI Lubuklinggau. 
Di lain pihak untuk hal lain yang dapat mempengaruhi kesegaran jasmani itu sendiri adalah gaya hidup, rokok, alkohol dan pengaruh latihan. Gaya hidup yang tidak tepat dapat menjadi penghalang kesegaran jasmani seseorang, seperti kebiasaan merokok, minum alkohol. Dengan kebiasaan yang tidak sehat tersebut, seseorang tidak hanya menjadi tidak segar tetapi juga akan menimbulkan penyakit bagi dirinya. Untuk itu perlu suatu program orientasi kesegaran jasmani bagi seseorang, khususnya bagi mahasiswa Penjaskes angkatan 2016 STKIP-PGRI Lubuklinggau. Di samping itu sebaiknya juga didukung dengan program latihan yang baik, agar menjadi pribadi yang terlatih dan lebih efisien.

\section{SIMPULAN}

Berdasarkan hasil penelitian tentang studi tingkat kesegaran jasmani mahasiswa Penjaskes angkatan 2016 STKIP-PGRI Lubuklinggau dapat dikemukakan kesimpulan yaitu dari 18 orang responden menunjukkan bahwa tingkat kesegaran jasmani pada klasifikasi "Baik Sekali" frekuensi $=8(44.44 \%)$ "Baik" frekuensi $=6$ (33.33\%), "Sedang " frekuensi $=4(22.22 \%)$, "Kurang" dan "Sangat Kurang" tidak ada $(0.00 \%)$. Penelitian menunjukkan mayoritas tingkat kesegaran jasmani mahasiswa tergolong baik sekali dan hanya sedikit dengan tingkat kesegaran jasmani kurang. Dengan demikian, dapat disimpulkan bahwa tingkat kesegaran jasmani mahasiswa Penjaskes STKIP-PGRI Lubuklinggau hampir keseluruhan tergolong baik..

\section{DAFTAR PUSTAKA}

Abdullah A. \& Agus M. (1994). Dasar-Dasar Pendidikan Jasmani. Jakarta. Dirjen Pendidikan Tinggi Depdikbud.

Arikunto, S. (1997). Dasar-dasar Evaluasi Pendidikan. (Edisi Revisi). Jakarta: Bumi Aksara

Arsil. (1999). Pembinaan Kondisi Fisik. Padang : FIK UNP.

Darwin. (1992). Daya Tahan Tubuh. Jakarta: Pustaka Setia

Soemosasmito, S. (1998). Dasar, Proses dan Efektifitas Belajar Mengajar Pendidikan Jasmani. Jakarta : Departemen Pendidikan dan Kebudayaan

Sudijono, A. (1991). Pengantar Statistik Pendidikan. Jakarta: Rajawali

Sudoso. (1990). Tingkat Kesegaran Jasmani. Bandung: Alphabeta

Sudarno. (1992). Kesegaran Jasmani dan Daya Tahan. Yugyakarta: Arruzmedia

Undang-Undang Republik Indonesia No.3 Tahun 2005.Sistem Keolahragan Nasional. Bandung : Citra Umbara

Djoko. (2004). Tingkat Kesegaran Jasmani. Jakarta: Gramedia

Harsono. (1988). Kesegaran Jasmani dan Daya Tahan. Yugyakarta: Arruzmedi 
